Article

\title{
Evaluation of Anthracnose Resistance in Pepper (Capsicum spp.) Genetic Resources
}

\author{
Na-Young Ro ${ }^{1, *}$, Raveendar Sebastin ${ }^{1}$, On-Sook Hur ${ }^{1}$, Gyu-Taek Cho ${ }^{1}$, Bora Geum ${ }^{1}$, Yong-Jik Lee ${ }^{2}$ \\ and Byoung-Cheorl Kang ${ }^{3}$ \\ 1 National Agrobiodiversity Center, National Institute of Agricultural Sciences, Rural Development \\ Administration, Jeonju 54874, Korea; raveendars@gmail.com (R.S.); oshur09@korea.kr (O.-S.H.); \\ gtcho@korea.kr (G.-T.C.); gbora27@korea.kr (B.G.) \\ 2 HANA SEED, Anseong 456-841, Korea; kamsay45@gmail.com \\ 3 Department of Plant Science, Plant Genomics and Breeding Institute and Vegetable Breeding Research Center, \\ College of Agriculture and Life Sciences, Seoul National University, Seoul 08826, Korea; bk54@snu.ac.kr \\ * Correspondence: nonanona@korea.kr
}

check for updates

Citation: Ro, N.-Y.; Sebastin, R.; Hur, O.-S.; Cho, G.-T.; Geum, B.; Lee, Y.-J.; Kang, B.-C. Evaluation of Anthracnose Resistance in Pepper (Capsicum spp.) Genetic Resources. Horticulturae 2021, 7, 460. https:// doi.org/10.3390/horticulturae7110460

Academic Editor: Jiatao Xiè

Received: 8 September 2021

Accepted: 1 November 2021

Published: 3 November 2021

Publisher's Note: MDPI stays neutral with regard to jurisdictional claims in published maps and institutional affiliations.

Copyright: (c) 2021 by the authors. Licensee MDPI, Basel, Switzerland. This article is an open access article distributed under the terms and conditions of the Creative Commons Attribution (CC BY) license (https:// creativecommons.org/licenses/by/ $4.0 /)$.
Abstract: Anthracnose (Colletotrichum spp.), is one of the major yield losing fungal disease in both pre- and post-harvest stage of pepper (Capsicum spp.) production worldwide. Among the Colletotrichum spp., C. acutatum has strong pathogenicity, which infects both immature and mature pepper fruit leads to severe economic losses in pepper production. Inheritance of anthracnose disease resistance was evaluated with 3738 pepper genetic resources which was collected from different countries and conserved at Korean genebank. The resistance analysis against pepper anthracnose (C. acutatum) was performed on detached mature green and red fruits under laboratory conditions by spray (non-wounding) and microinjection (wounding) inoculation methods. In the primary screening, about 261 accessions were appeared to be resistant against C. acutatum in spray inoculation. The resistant accessions were further evaluated with microinjection (wounding) inoculation method using the fungal (C. acutatum) isolate of pepper anthracnose. There were highly significant differences in the disease severity and distribution of disease rating scale, considering all the sources has significant genetic variation. Finally, the anthracnose resistant pepper accessions have been validated with cleaved amplified polymorphic sequence (CAPS) and high-resolution melting (HRM) markers in which, the CAPS and HRM marker analysis showed four types of genotypes such as resistant $(\mathrm{R})$, susceptible $(\mathrm{S})$, heterozygous $(\mathrm{H})$ and Unidentified type (UT) or not detection. The Capsicum accessions showing high level of resistance to the pathogen could be used as source material in breeding programs for resistance to anthracnose disease.

Keywords: anthracnose resistance; Capsicum; Colletotrichum spp.; pepper genetic resources

\section{Introduction}

The Capsicum L. (Solanaceae) represents a diverse plant group contains a large number of cultivated species as well as wild species that are grown for their fruits, and are an important vegetable consumed throughout the world. Approximately, 25 Capsicum species have been cultivated extensively [1] and being used as food flavoring, pharmaceutical ingredient, coloring agent and in many other innovative ways [2]. Systemically, the genus Capsicum was classified by its flower, fruit structure and chromosome number [3]. Similarly, Capsicum species have been divided into three complexes such as, C. annuum, C. baccatum and C. pubescens complexes based on cytogenetics and cross fertility [4]. However, the wild ancestor of Capsicum species remains unclear; due to some wild species have a predominant chromosome numbers [5,6]. Wild species of Capsicum are important sources of genetic diversity and reservoirs of genes for breeding programs of cultivated pepper [7]. Hence, conservation of wild genotypes and screening for novel allele is an increasing 
priority to make modern cultivars which gradually substitutes the landraces to increase productivity [8].

Anthracnose, is one of the serious fungal disease in pepper fruit caused by Colletotrichum spp. such as C. acutatum, C. capsici, and C. gloeosporioides, leads to significant yield losses worldwide [9]. However, in Korea the C. acutatum species complex is a most significant causal pathogen of the disease, which infects both immature and mature pepper fruits [10]. Typical anthracnose symptoms on pepper fruit includes sunken necrotic tissues, with concentric rings of acervuli which reduce fruit quality [11]. In general, the anthracnose disease was controlled by using chemical fungicides which might have negative impact on human health and pollute the environment. Biocontrol agents such as Bacillus sp. and its putative catalase may be useful to protect pepper from anthracnose [12]. However, the development of resistant cultivars is the best long-term strategy to control the disease, and so it is a very important goal for pepper breeders. There is still little information available about the interactions between the host and the causal pathogens of pepper anthracnose [9].

Breeding for anthracnose resistance began in the early 1990s, involving some Capsicum species such as, C. annuum, C. frutescens, and C. baccatum with potential resistance traits. It suggested that the $C$. baccatum germplasm contained higher levels of resistance to anthracnose, which may prove useful as genetic resources for anthracnose resistance [13]. Marker-assisted selection is a significant tool for the breeding of pepper. Anthracnose resistance is controlled by a major resistance locus and STS marker (CaR12.2M1-CAPS) was developed $[14,15]$. The introgression of the resistance gene from C. baccatum to C. annuum is difficult. For example, $\mathrm{PBC} 80$ was introduced into $C$. annuum through a tri-species cross by using $C$. chinense as an intermediate host [16]. New crosses have been created to combine a good source of disease resistance, such as the C. chinense germplasm selection PBC932, with elite Indonesian OP varieties, primarily "Jatilaba", "TitSuper" and "KR-B" ("Keriting" from Bogor). In Korea, resistant varieties, "AR legend", that crossed from C. baccatum to C. annuиm with embryo rescue had been developed since 2014 . There were several studies focused on the introgression of anthracnose resistance into $C$. annuum to develop new varieties $[17,18]$.

Genetic resources with excellent disease resistance are an important prerequisite for the development of elite varieties [19]. Various studies have been reported for evaluation of C. acutaum resistance in pepper genetic resources [13,20-22]. Similarly different methods such as, anthracnose inoculation method, wounding and non-wounding inoculation method have been reported [23]. Non-wounding inoculation could evaluate resistance to anthracnose for cuticular wax defense of the fruit. Anthracnose development as negatively related with fruit developmental stage. As well-developed fruits had more cuticular wax than less developed fruits, the cuticular wax layers of pepper fruits may play a significant role in fruit infection by C. gloeosporioides isolate KG13 [24].

Phenotypic and genotypic characterization of a resistance gene (AVPP0207) located on chromosome P5 of $C$. annuum (progressive line derived from PBC932) was reported against two anthracnose isolates of $C$. acutatum and C. truncatum [25]. The fine mapping of a major anthracnose resistance QTL AnRGO5 in C. chinense 'PBC932' was also reported [26]. However, the resistance genes in C. chinense and C. baccatum were differentially expressed at different fruit maturity stages. Alternatively, some recent research reported that the inheritance of anthracnose resistance is controlled by recessive genes [27]. The finding of the study revealed that, in mature green fruit, the resistance gene is the recessive gene co1, while in ripe fruit and seedlings, the recessive genes $\mathrm{co} 2$ and co3, respectively, are responsible for anthracnose resistance. Mahasuk et al. found that the resistance at the ripe red fruit and mature green stages is controlled by a single dominant and single recessive gene, respectively, between an intraspecific cross derived from C. baccatum PBC1422 and PBC80 [28].

Sources of anthracnose resistance in C. chinense L. and C. baccatum Jacq. have been reported in Asia and used as parents in breeding programs [29]. In Korea, some studies 
searching for anthracnose resistance sources have been performed [13,21,30]. However, screening for inheritance of anthracnose resistance in the wild as well as the domesticated Capsicum species against Colletotrichum are still lacking, particularly for C. scovillei (formerly known as C. acutatum). The aim of this study was to find anthracnose resistant genetic resources and make these materials available for breeding purposes.

\section{Materials and Methods}

\subsection{Plant Materials}

A total of 3738 accessions used in this study originated from 112 countries (Table 1) which includes 12 Capsicum species such as, C. annuum, C. baccatum, C. glabriusculum, C. chacoense, C. chinense, C. eximium, C. frutescens, C. galapagoense, C. pendulum, C. praetermissum, C. pubescens, and $C$. tovarii. The geographic origin and passport data of the germplasm accessions were obtained from the National Agrobiodiversity Center (NAC, Jeonju, Korea). For each accession, 8 to 10 plants were planted in a greenhouse at NAC, Jeonju, Korea, and their genetic uniformity and fruit characteristics was evaluated. The plants were irrigated with standard cultivation method made by the Rural Development Administration (RDA, Jeonju, Korea). Fully grown green fruit (approximately 30 days after pollination) were used for the postharvest inoculation test. In the experiments, C. annuum 'Manitta' (Nongwoobio Co.) was used as a susceptible control, and 'AR- Dolgyeoktan' (Pepper and breeding Co.), PBC81 and PI594137, were used as resistant control [21].

Table 1. Origin distribution of Capsicum genetic resources for evaluation of resistance against anthracnose disease in this study.

\begin{tabular}{|c|c|c|}
\hline Continent & $\begin{array}{c}\text { No. of } \\
\text { Accession }\end{array}$ & Country * \\
\hline South America & 885 & $\begin{array}{c}\text { ARG, BOL, BRA, CHL, COL, ECU, GUY, PER, PRI, PRY, } \\
\text { SUR, URY, VEN }\end{array}$ \\
\hline North America & 585 & $\begin{array}{c}\text { BHS, BLZ, CAN, CRI, CUB, GRD, GTM, HND, JAM, } \\
\text { MEX, NIC, PAN, SLV, USA, VIR }\end{array}$ \\
\hline Asia & 1185 & $\begin{array}{c}\text { AFG, ARM, AZE, BGD, BTN, CHN, GEO, IDN, IND, IRN, } \\
\text { IRQ, ISR, JPN, KAZ, KGZ, KHM, KOR, LAO, LKA, MDV, } \\
\text { MMR, MNG, MYS, NPL, PAK, PHL, PRK, SYR, THA, TJK, } \\
\text { TKM, TUR, TWN, UZB, VNM, YEM }\end{array}$ \\
\hline Africa & 61 & $\begin{array}{l}\text { MAR, BFA, BWA, DZA, EGY, ETH, GAB, GIN, KEN, LBY, } \\
\text { MWI, NGA, SDN, SEN, TUN, TZA, UGA, ZAR, ZMB }\end{array}$ \\
\hline Oceania & 9 & AUS, FJI, PNG \\
\hline Europe & 724 & $\begin{array}{l}\text { SUN, AUT, BEL, BGR, BLR, CHE, CSK, CZE, DEU, DNK, } \\
\text { ESP, FRA, GBR, GRC, HUN, ITA, MDA, NLD, PRT, ROM, } \\
\text { RUS, SRB, SVK, UKR, YUG }\end{array}$ \\
\hline Unknown & 289 & \\
\hline Total & 3738 & \\
\hline
\end{tabular}

* Abbreviation: see Appendix A.

\subsection{Inoculum Preparation}

The fungal (C. acutatum) isolate 'KSCa-1' was obtained from Lee et al. [14] and the culture inoculum preparation was followed the procedures of Kim et al. [21]. The isolates were grown on potato dextrose agar (PDA) plates (Sigma Chemical Co., St. Louis, MO, USA) at $28^{\circ} \mathrm{C}$ under $16 \mathrm{~h}$ fluorescent light $/ 8 \mathrm{~h}$ dark in a temperature controlled incubation chamber. Seven-day-old PDA plates were flooded with distilled water, and fungal cultures were gently scraped from the plates. Inoculum density was adjusted to $1.0 \times 10^{5}$ conidia $/ \mathrm{mL}$ with a hemacytometer.

\subsection{Inoculation Method}

Two different artificial inoculation such as, post-harvest wound and non-wound inoculations methods were used. For non-wound inoculation, fully grown green pepper 
fruits 10 per accessions were kept in a re-sealable plastic bag $(25 \times 30 \mathrm{~cm})$ with paper towel. The fruit surface was sprayed with inoculum containing anthracnose spores adjusted to a concentration of $1.0 \times 10^{5}$ conidia/mL. Inoculated peppers were sealed immediately and kept in thermostat at $28{ }^{\circ} \mathrm{C}$ in order to maintain the humidity for disease induction. After two days of incubation, the re-sealable plastic bags opened at room temperature for $2 \mathrm{~h}$ to prevent the corruption due to excessive humidity and incubated again for 14 days under the same conditions.

In wound inoculation method, microinjection by using a gas-tight micro-syringe and needle with adjustable wounding depth was used. The detached fruits 10 per accessions were washed with distilled water and on the epidermis, one to five sites according to fruit sizes were injected with $10 \mu \mathrm{L}$ of conidial suspension containing $1.0 \times 10^{5}$ conidia $/ \mathrm{ml}$. The inoculated fruits were placed in acrylic boxes moistened with four layers of wet paper towel. The boxes were tightly sealed to maintain more than $95 \%$ relative humidity and were incubated at $28{ }^{\circ} \mathrm{C}$ with $16 \mathrm{~h}$ light period of up to $48 \mathrm{~h}$. Finally, the boxes were uncovered and incubated again for 10 days under the same conditions.

\subsection{Disease Evaluation}

The percentage of infected sites was calculated to evaluate the disease severity of non-wounding with an average of 14 days after inoculation (Figure 1a). Based on the score, a disease rating scale (DRS) was established from 0 to $4: 0=$ no symptoms; $1=$ symptoms with $<10 \%$ disease incidence; 2 = symptoms with $11-20 \% ; 3=$ symptoms with $21-40 \%$; 4 = symptoms with $41-100 \%$ disease incidence. The phenotypes with a mean disease rating scale of $<1$ were evaluated as resistant (R), 1-2 as moderately resistant (MR); 2-3 as susceptible (S); and 4 as highly susceptible (HS).
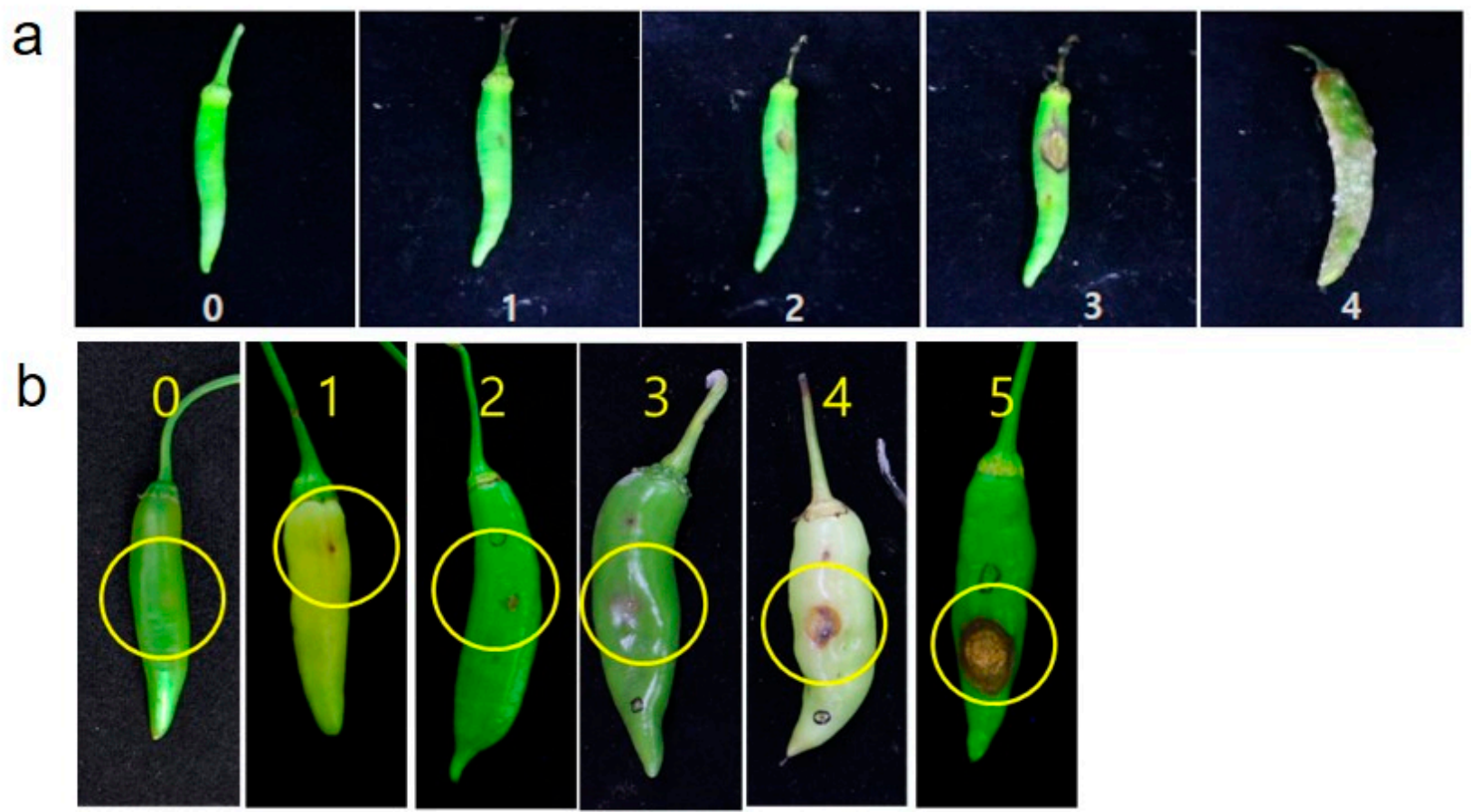

Figure 1. Disease severity of C. acutatum according to symptoms of each inoculation method. (a) Disease rating scale (0-4) of non-wounding inoculation (spray) and (b) Disease rating scale (0-5) of wound inoculation (microinjection).

Similarly, the disease severity of wound inoculation was scored finally at 2 weeks of post inoculation (Figure $1 \mathrm{~b}$ ) based on the disease rating scale $0-5$ where $0=$ no visible symptoms observed; 1 = symptoms of a size less than $2 \mathrm{~mm} ; 2=$ symptoms of a size less than $4 \mathrm{~mm} ; 3=$ symptoms of a size less than $6 \mathrm{~mm} ; 4=$ symptoms of a size less than $10 \mathrm{~mm} ; 5$ = more than $10 \mathrm{~mm}$ often encircling with acervuli as reported by Kim et al. [21]. 
Phenotypes with a mean disease rating scale of $<1$ were evaluated as resistant (R), $1-2$ as moderately resistant (MR); $2-4$ as susceptible (S); and $>4$ as highly susceptible (HS).

\subsection{DNA Extraction and HRM Maker Analysis}

Genomic DNA was extracted using the CTAB method [13]. The CA12g19240-HRM marker [31] and the CaR12.2M1-CAPS marker [15] were used to analyze the pepper genetic resources. The CA12g19240-HRM marker analysis was performed in a total reaction volume of $20 \mu \mathrm{L}$, containing $10 \mathrm{ng}$ of genomic DNA, $2.0 \mu \mathrm{L}$ of $10 \times$ Taq buffer (Bioneer Co., Daejeon, Korea), $1.0 \mu \mathrm{L}$ of $2.5 \mathrm{mM}$ dNTP mixture, $0.1 \mu \mathrm{L}$ of Taq DNA polymerase (Bioneer Co.), $1.0 \mu \mathrm{L}$ of $\mathrm{SYTO}^{\circledR} 9$ green fluorescent nucleic acid stain (Life Technologies ${ }^{\mathrm{TM}}$, Carlsbad, CA, USA), $0.5 \mu \mathrm{L}$ each of $10 \mathrm{pmol} \mu \mathrm{L}^{-1}$ of a pair of primers [32], and autoclaved distilled water for the remainder of the volume. HRM was analyzed using the LightCycler ${ }^{\circledR}$ 96 Real-Time PCR System (Roche, Basel, Switzerland) as follows; initial denaturation at $95^{\circ} \mathrm{C}$ for $5 \mathrm{~min}$; denaturation at $95^{\circ} \mathrm{C}$ for $10 \mathrm{~s}$, and annealing and elongation at $60^{\circ} \mathrm{C}$ for $20 \mathrm{~s}$, repeated 40 times; and final denaturation at $95^{\circ} \mathrm{C}$ for $10 \mathrm{~s}$; and $\mathrm{HRM}$ was analyzed at each temperature during a rise of $0.3 \%$ from 60 to $90{ }^{\circ} \mathrm{C}$. The HRM graphs were drawn by LightCycler ${ }^{\circledR} 96$ software ver. 1.1 (Roche). The CaR12.2M1-CAPS marker analysis was performed with PCR program as follows: an initial denaturation at $95^{\circ} \mathrm{C}$ for $5 \mathrm{~min} ; 40$ cycles of amplification, each consisting of $95^{\circ} \mathrm{C}$ for $45 \mathrm{~s}, 66^{\circ} \mathrm{C}$ for $45 \mathrm{~s}$, and $72{ }^{\circ} \mathrm{C}$ for $1 \mathrm{~min}$; and a final extension at $72{ }^{\circ} \mathrm{C}$ for $5 \mathrm{~min}$. The PCR production CAPS analysis was digested with the restriction enzyme BglII, and then separated on $1.2 \%$ agarosegels.

\subsection{Fruit Characterization and Statistical Analyses}

The fruit qualitative characters observed were fruit color at immature and mature stage, fruit shape, fruit color at mature stage, and fruit surface, while fruit quantitative traits including fruit length and width, fruit wall thickness, sugar contents and fruit weight were measured 3 per accession. These characters were measured at various growth stages using the standard descriptors for Capsicum developed by RDA [33]. Qualitative and quantitative data were analyzed using Microsoft Excel (version 16.0, Microsoft, Redmond, WA, USA). Descriptive statistics were performed using R Program (Version 4.0.2).

\section{Results}

\subsection{Pepper Germplasm against C. acutatum with Non-Wound Inoculation}

Evaluation of fungal disease resistance against the $C$. acutatum was conducted with a total of 3738 pepper germplasm. Based on the non-wounding inoculation, 261 pepper germplasm accessions showed disease resistance against $C$. acutatum infection (Table 2). Among the tested germplasm resources, 51 accessions were belonging to $C$. annuum and C. annuum var. annuum, 32 accessions were C. baccatum, C. baccatum var. baccatum, and C. baccatum var. pendulum, 84 accessions were C. chinense, and 86 accessions were C. frutescens of domesticated species. In C. chacoense, three and two accessions were showed as resistant and MR, respectively, and the other accession were susceptible to the infection. Similarly, two C. pubescens accessions were exhibited as MR and the remaining accessions turned out to be susceptible to the disease. The tested C. eximium and C. galapagoense accessions were showed susceptible, whereas the $C$. tovarii accession was showed resistant to the disease infection. Based on non-wounding inoculation, there were no significant difference between domesticated and wild species in disease resistance.

The development of anthracnose symptoms on susceptible and resistant Capsicum accessions by non-wounding spray inoculation with a concentration of $1.0 \times 10^{5}$ conidia $/ \mathrm{mL}$ is shown in Figure 2. The typical anthracnose disease symptoms were developed on accessions of Capsicum spp., after 14 days of inoculation. The initial sunken symptoms of anthracnose were formed seven days after inoculation on susceptible accessions and increased the lesions size on fruits. 
Table 2. Distribution of disease rating scale among the tested pepper germplasm resources against $C$. acutatum by non-wounding inoculation.

\begin{tabular}{|c|c|c|c|c|c|}
\hline \multirow{2}{*}{ Species } & \multicolumn{4}{|c|}{ Disease Rating Scale } & \multirow{2}{*}{ Total } \\
\hline & 0-1 (R) & 1-2 (MR) & $2-3(S)$ & 3-4 (HS) & \\
\hline C. annuum & 2 & 3 & 8 & 684 & 697 \\
\hline C. annuum var annuum & 49 & 27 & 26 & 1213 & 1315 \\
\hline C. annuum var glabriusculum & 1 & - & - & 3 & 4 \\
\hline C. baccatum & 18 & 12 & 6 & 55 & 91 \\
\hline C. baccatum var baccatum & 9 & 8 & 15 & 136 & 168 \\
\hline C. baccatum var pendulum & 5 & 15 & 6 & 97 & 123 \\
\hline C. baccatum var praetermissum & - & - & - & 4 & 4 \\
\hline C. chacoense & 3 & 2 & - & 12 & 17 \\
\hline C. chinense & 84 & 43 & 40 & 512 & 679 \\
\hline C. eximium & - & - & - & 1 & 1 \\
\hline C. frutescens & 86 & 35 & 36 & 308 & 465 \\
\hline C. galapagoense & - & - & - & 2 & 2 \\
\hline C. pubescens & - & 2 & 2 & 25 & 29 \\
\hline C. tovarii & 1 & - & - & - & 1 \\
\hline C. $s p$. & 3 & - & 1 & 138 & 142 \\
\hline Total & 261 & 147 & 140 & 3190 & 3738 \\
\hline
\end{tabular}
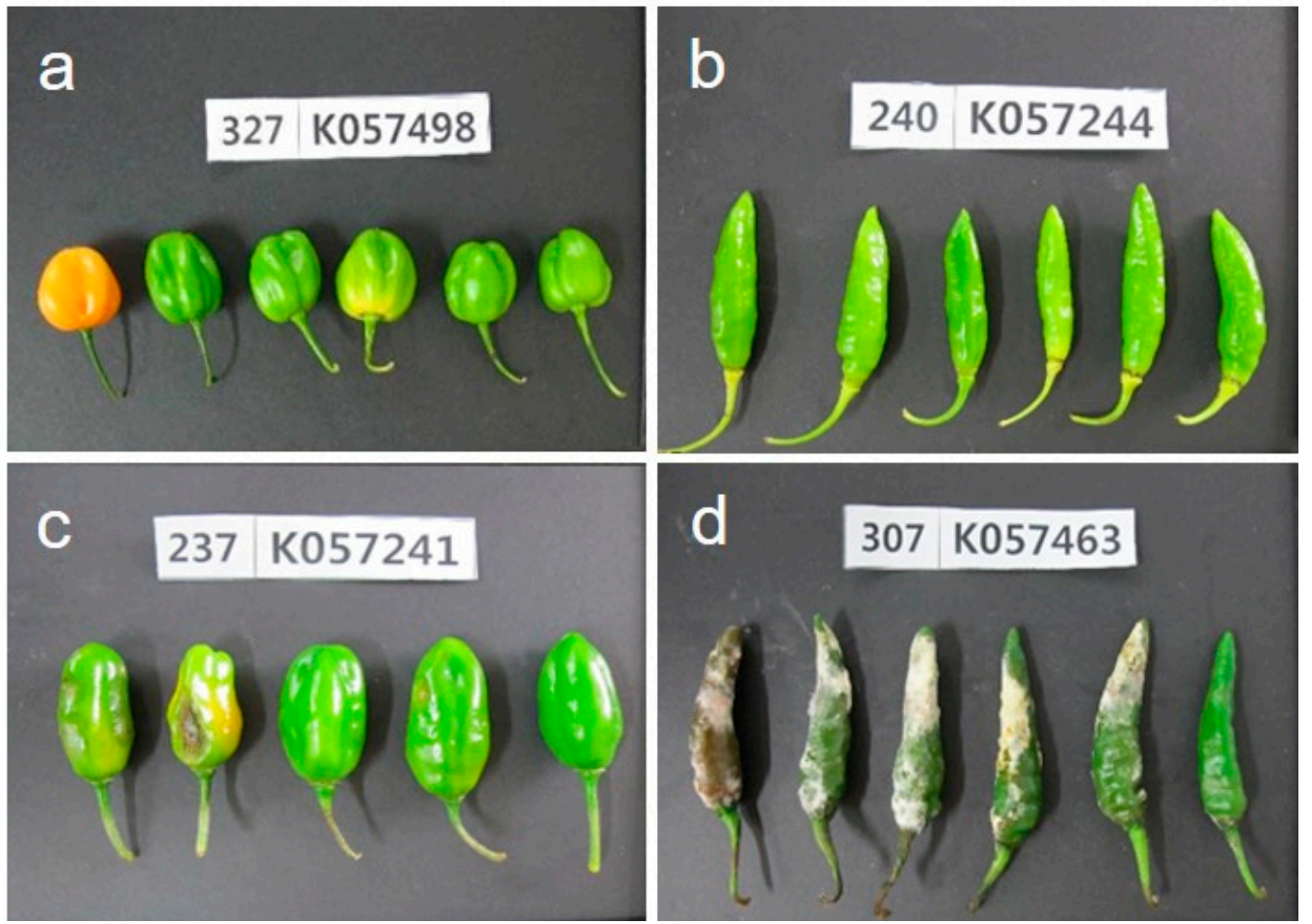

Figure 2. Disease symptoms of fruits after 14 days of non-wounding inoculation with C. acutatum isolate 'KSCa-1'. (a) resistant reaction of C. chinense; (b) resistant reaction of C. baccatum; (c) moderate resistant reaction of $C$. chinense; and (d) susceptible reaction of $C$. annuum.

\subsection{Pepper Germplasm against C. acutatum with Wound Inoculation}

To evaluates the fungal disease resistance against the C. acutatum, 215 pepper genetic resources were treated with wound inoculation method (Table 3). Based on nonwounding inoculation, 261 accessions were appeared resistant to the fungal disease in which 215 accessions were selected for wounding inoculation. Among the 215 tested germplasm, seven accessions of C. baccatum, C. baccatum var. baccatum, and C. baccatum var. pendulum, four accessions of $C$. chinense and a single accession of $C$. frutescens were 
appeared with less than $25 \%$ disease incidence. Based on wound inoculation, all the selected $C$. annuum and C. annuum var. annuum accessions were appeared with more than $50 \%$ disease incidence.

Table 3. Distribution of disease incidence among the selected pepper germplasm resources against C. acutatum by wound inoculation.

\begin{tabular}{|c|c|c|c|c|c|}
\hline \multirow{2}{*}{ Species } & \multicolumn{4}{|c|}{ Disease Incidence (\%) } & \multirow{2}{*}{ Total * } \\
\hline & $0-25$ & $25-50$ & $50-75$ & 75-100 & \\
\hline C. annuum & - & - & 1 & 2 & $3^{\mathrm{ab}}$ \\
\hline C. annuum var. annuum & - & - & - & 5 & $5^{a b}$ \\
\hline C. baccatum & 3 & 3 & 9 & 9 & $24^{b}$ \\
\hline C. baccatum var. baccatum & 2 & 5 & 12 & 10 & $29 \mathrm{ab}$ \\
\hline C. baccatum var. pendulum & 2 & 6 & 5 & 9 & $22^{b}$ \\
\hline C. chacoense & - & - & - & 5 & $5^{a}$ \\
\hline C. chinense & 4 & 5 & 20 & 79 & $108^{a b}$ \\
\hline C. frutescens & 1 & 1 & 7 & 8 & $17^{a b}$ \\
\hline C. pubescens & - & - & 1 & - & $1^{\mathrm{ab}}$ \\
\hline C. sp. & - & - & 1 & - & $1^{-}$ \\
\hline Total & 12 & 20 & 56 & 127 & 215 \\
\hline
\end{tabular}

* Means the same letter are not significantly different in Duncan's multiple range test ( $p \leq 0.05)$.

After 3 days of microinjection based wound inoculation, the pin picking area began to sunken with necrotic tissues formed water-soaked lesions, which makes concentric rings of acervuli. In the wound inoculation, the typical anthracnose disease symptoms were developed on the accession of Capsicum spp. at 5 7 days after inoculation (Figure 3). The results of Duncan's test on disease incidence rates with 214 Capsicum resources excluding a Capsicum spp. revealed that the accessions of $C$. chacoense formed a single group (Table 3). Similarly, the accessions of $C$. bacatum and C. baccatum var. pendulum were divided into individual group, whereas the $C$. baccatum var. baccatum, C. chinense, $C$. frutescens, C. pubescens, C. annuum, and C. annuum var. annuum accessions were grouped together.

\subsection{Maker Validation}

Based on the inoculation experiment results, 261 resistant accessions were selected for marker validation. The base substitution for the anthracnose resistant $(R)$ to susceptible (S) marker type was A $\rightarrow$ G, which was analyzed with the selected accessions. The SNP locus was converted to CAPS marker for detecting potential diversity in the Capsicum accessions (Table 3). The amplified SNP loci was analyzed with restriction enzyme BglII (NEB; Ipswich, England), in which SNP variations were observed with specific restriction fragment patterns (Figure 4). The results confirmed that CaR12.2M1-CAPS marker had four different restriction profiles as resistant $(\mathrm{R})$, susceptible $(\mathrm{S})$, heterozygous $(\mathrm{H})$ and Unidentified type (UT). In order to confirm the diversity of the SNP loci among the accession, 15 accessions were selected with varying disease index $(0-5)$, which confirmed the four different restriction profiles as resistant (R), susceptible (S), heterozygous $(\mathrm{H})$ and Unidentified type (UT) or not detection (Table 4). In the CA12g19240 HRM analysis, the SNP locus showed a unique melting curve, and each accession was stratified into three groups (Figure 4) as resistant (R), susceptible (S), and heterozygous $(\mathrm{H})$. 


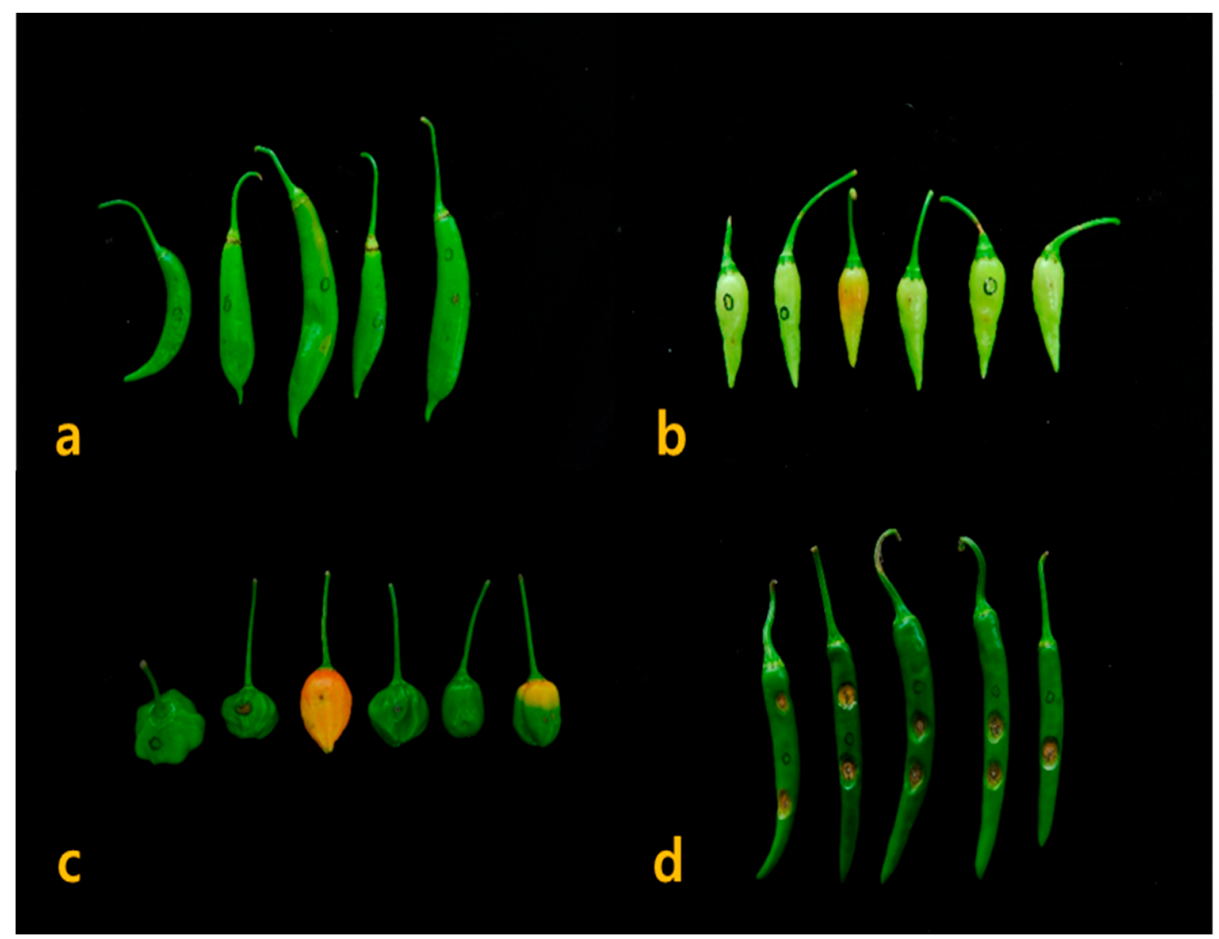

Figure 3. Anthracnose symptoms on resistant and susceptible Capsicum accessions. Resistant response of (a) C. baccatum and (b) C. chinense; Moderate resistant response of (c) C. chinense and Susceptible response of (d) C. annuum.
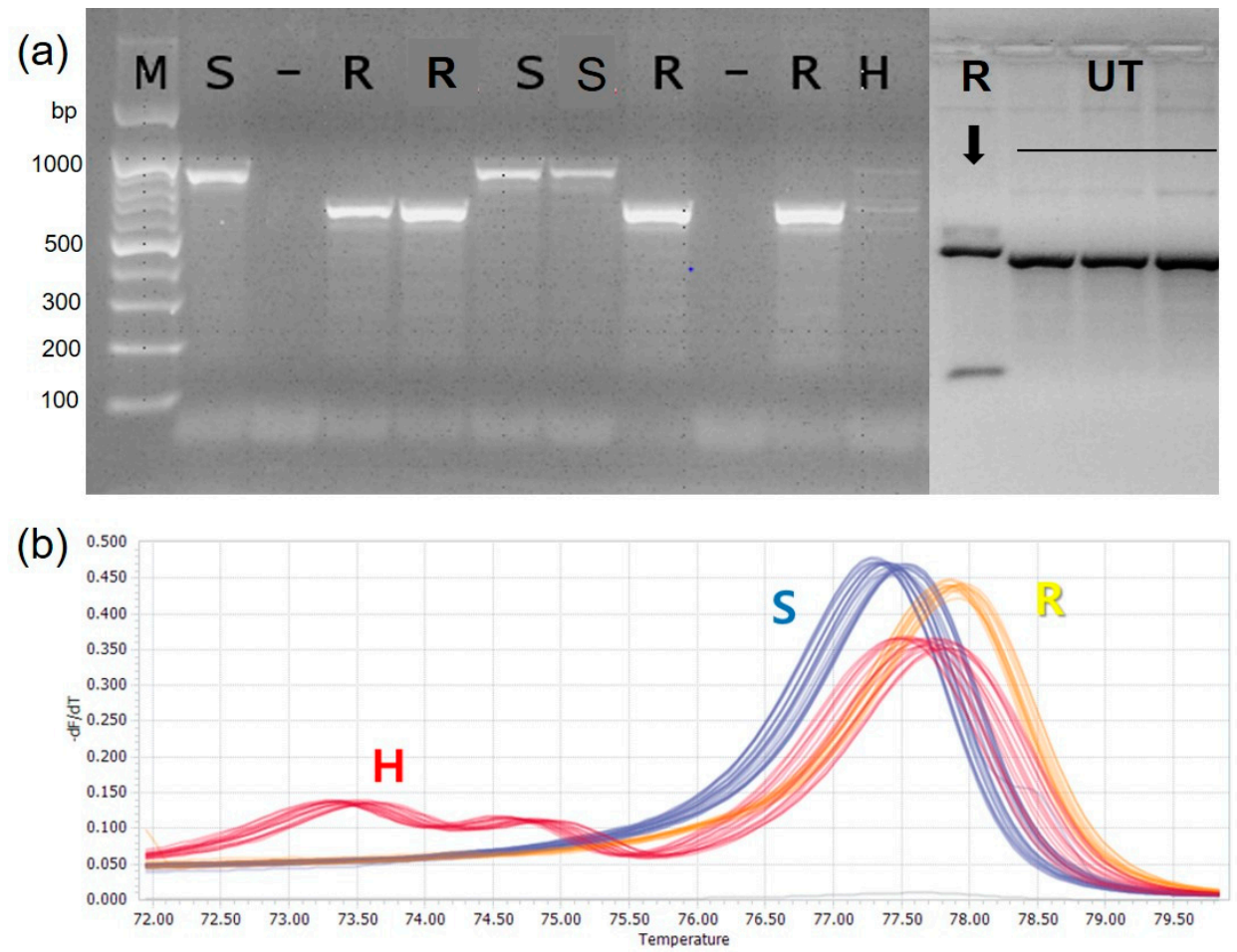

Figure 4. Examples of CaR12.2M1-CAPS Marker (a) and CA12g19240 HRM marker analysis (b). The CaR12.2M1-CAPS Marker analysis showed four types of genotype: resistant (R), susceptible (S), heterozygous (H) and Unidentified type (UT) along with 100 bp DNA size marker (M). The normalized melting peaks generated by CA12g19240 HRM marker analysis showed three types of genotypes: resistant $(\mathrm{R})$, susceptible $(\mathrm{S})$ and heterozygous $(\mathrm{H})$. 
Table 4. Incidence and Reaction to CA12g19240 and CaR12.2M1-CAPS marker of Pepper genetic resources selected with non-wound and wound inoculation.

\begin{tabular}{|c|c|c|c|c|c|c|}
\hline Acc. No. & Species & Incidence (\%) & Lesion (mm) & Disease Rating Scale & CA12g19240 & CaR12.2M1-CAPS \\
\hline 158502 & C. chinense & 14.3 & $1.4 \pm 0.5$ & 1 & $\mathrm{~S} /-$ & $\mathrm{S} / \mathrm{Ud}$ \\
\hline 158769 & $\begin{array}{l}\text { C. baccatum var. } \\
\text { pendulum }\end{array}$ & 22.2 & $2.0 \pm 0.7$ & 1 & $\mathrm{R}$ & $\mathrm{R}$ \\
\hline 218958 & $\begin{array}{l}\text { C. baccatum var. } \\
\text { baccatum }\end{array}$ & 16.7 & $1.6 \pm 0.6$ & 1 & $\mathrm{R}$ & $\mathrm{R}$ \\
\hline 229147 & $\begin{array}{l}\text { C. baccatum var. } \\
\text { baccatum }\end{array}$ & 20 & $2.0 \pm 1.2$ & 1 & $\mathrm{R}$ & $\mathrm{R}$ \\
\hline 229200 & C. chinense & 11.1 & $0.9 \pm 0.3$ & 1 & S & S \\
\hline 240869 & C. baccatum & 15.8 & $1.5 \pm 0.7$ & 1 & $\mathrm{R}$ & $\mathrm{R}$ \\
\hline 258953 & C. baccatum & 22.8 & $3.9 \pm 1.3$ & 2 & $\mathrm{R}$ & $\mathrm{R}$ \\
\hline 270479 & C. chinense & 10 & $0.3 \pm 0.2$ & 1 & S & S \\
\hline 276470 & C. frutescens & 25 & $5.3 \pm 1.5$ & 3 & $\mathrm{~S} /-$ & $\mathrm{S} / \mathrm{Ud}$ \\
\hline 305437 & C. chinense & 20 & $0.5 \pm 0.4$ & 1 & $\mathrm{~S}$ & $\mathrm{~S}$ \\
\hline 305455 & C. chinense & 10 & $0.3 \pm 0.2$ & 1 & $\mathrm{~S}$ & $\mathrm{~S}$ \\
\hline 305478 & C. baccatum & 10 & $0.5 \pm 0.3$ & 1 & $\mathrm{R}$ & $\mathrm{R}$ \\
\hline Manitta & C. аппиит & 100 & $13.7 \pm 2.1$ & 5 & S & S \\
\hline PBC81 & $\begin{array}{l}\text { C. baccatum var. } \\
\text { pendulum }\end{array}$ & 40 & $6.8 \pm 1.2$ & 4 & $\mathrm{R}$ & $\mathrm{R}$ \\
\hline AR-Dolgyeoktan & C. sp. & 42 & $6.9 \pm 1.6$ & 4 & $\mathrm{H}$ & $\mathrm{H}$ \\
\hline
\end{tabular}

Resistant (R), susceptible (S), Unidentified type (Ud), heterozygous (H) and '-' is not detection.

\subsection{Fruit Characteristics}

Five different fruit characteristics such as fruit weight $(\mathrm{g})$, length(cm), width(mm), wall thickness $(\mathrm{mm})$ and sugar content ( ${ }^{\circ}$ Brix) were investigated to use the selected pepper genetic resources for breeding materials (Table 5). Three to five fruits were surveyed from each resources. Fruit color and shape of the selected pepper genetic resources showed in Figure 5 .

Table 5. Fruit characteristics of selected anthracnose resistant Pepper genetic resources.

\begin{tabular}{|c|c|c|c|c|c|c|c|}
\hline Acc. No. & Origin & Species & $\begin{array}{c}\text { Fruit } \\
\text { Weight(g) }\end{array}$ & $\begin{array}{c}\text { Fruit } \\
\text { Length }(\mathrm{cm})\end{array}$ & $\begin{array}{c}\text { Fruit } \\
\text { Width(mm) }\end{array}$ & $\begin{array}{c}\text { Fruit wall } \\
\text { Thickness }(\mathrm{mm})\end{array}$ & $\begin{array}{l}\text { Sugar Content } \\
\left({ }^{\circ} \text { Brix }\right)\end{array}$ \\
\hline 158502 & PER & C. chinense & $21.3 \pm 0.8$ & $10.2 \pm 0.3$ & $26.4 \pm 0.8$ & $3.0 \pm 0.5$ & $9.1 \pm 0.2$ \\
\hline 158769 & CHL & $\begin{array}{l}\text { C. baccatum } \\
\text { var. pendulum }\end{array}$ & $22 \pm 1.6$ & $7.9 \pm 0.8$ & $26.5 \pm 0.7$ & $1.5 \pm 0.1$ & $12.9 \pm 0.3$ \\
\hline 218958 & VEN & $\begin{array}{l}\text { C. baccatum } \\
\text { var. baccatum }\end{array}$ & $15.9 \pm 1.8$ & $9.9 \pm 0.4$ & $27.1 \pm 0.6$ & $1.7 \pm 0.1$ & $15.8 \pm 0.6$ \\
\hline 229147 & HUN & $\begin{array}{l}\text { C. baccatum } \\
\text { var. baccatum }\end{array}$ & $6.4 \pm 0.7$ & $2.4 \pm 0.1$ & $21.2 \pm 0.8$ & $2.4 \pm 0.1$ & $8.5 \pm 0.6$ \\
\hline 229200 & HUN & C. chinense & $7.2 \pm 0.7$ & $6.3 \pm 0.3$ & $22.2 \pm 0.8$ & $1.9 \pm 0.1$ & $7.6 \pm 0.1$ \\
\hline 240869 & BRA & C. baccatum & $7.7 \pm 0.5$ & $5.8 \pm 0.2$ & $12.0 \pm 2.2$ & $2.0 \pm 0.5$ & $11.8 \pm 0.9$ \\
\hline 258953 & UNK & C. baccatum & $1.4 \pm 0.1$ & $2.6 \pm 0.1$ & $8.4 \pm 0.5$ & $1.0 \pm 0.1$ & $10.3 \pm 0.7$ \\
\hline 270479 & BRA & C. chinense & $1.3 \pm 0.1$ & $1.1 \pm 0.1$ & $14.1 \pm 0.1$ & $1.4 \pm 0.2$ & $8.4 \pm 0.9$ \\
\hline 276470 & CRI & C. frutescens & $6.7 \pm 0.1$ & $3.2 \pm 0.1$ & $21.8 \pm 0.6$ & $1.6 \pm 0.3$ & $9.3 \pm 0.4$ \\
\hline 305437 & $\mathrm{COL}$ & C. chinense & $8.8 \pm 0.6$ & $4.8 \pm 0.4$ & $23.2 \pm 1.3$ & $2.4 \pm 0.2$ & $7.8 \pm 0.4$ \\
\hline 305455 & $\mathrm{COL}$ & C. chinense & $4.5 \pm 1.0$ & $4.5 \pm 0.4$ & $22.2 \pm 2.2$ & $1.5 \pm 0.1$ & $10.2 \pm 0.5$ \\
\hline 305478 & PER & C. baccatum & $5.4 \pm 0.2$ & $4.5 \pm 0.1$ & $18.5 \pm 1.3$ & $2.7 \pm 0.5$ & $10.8 \pm 0.3$ \\
\hline
\end{tabular}




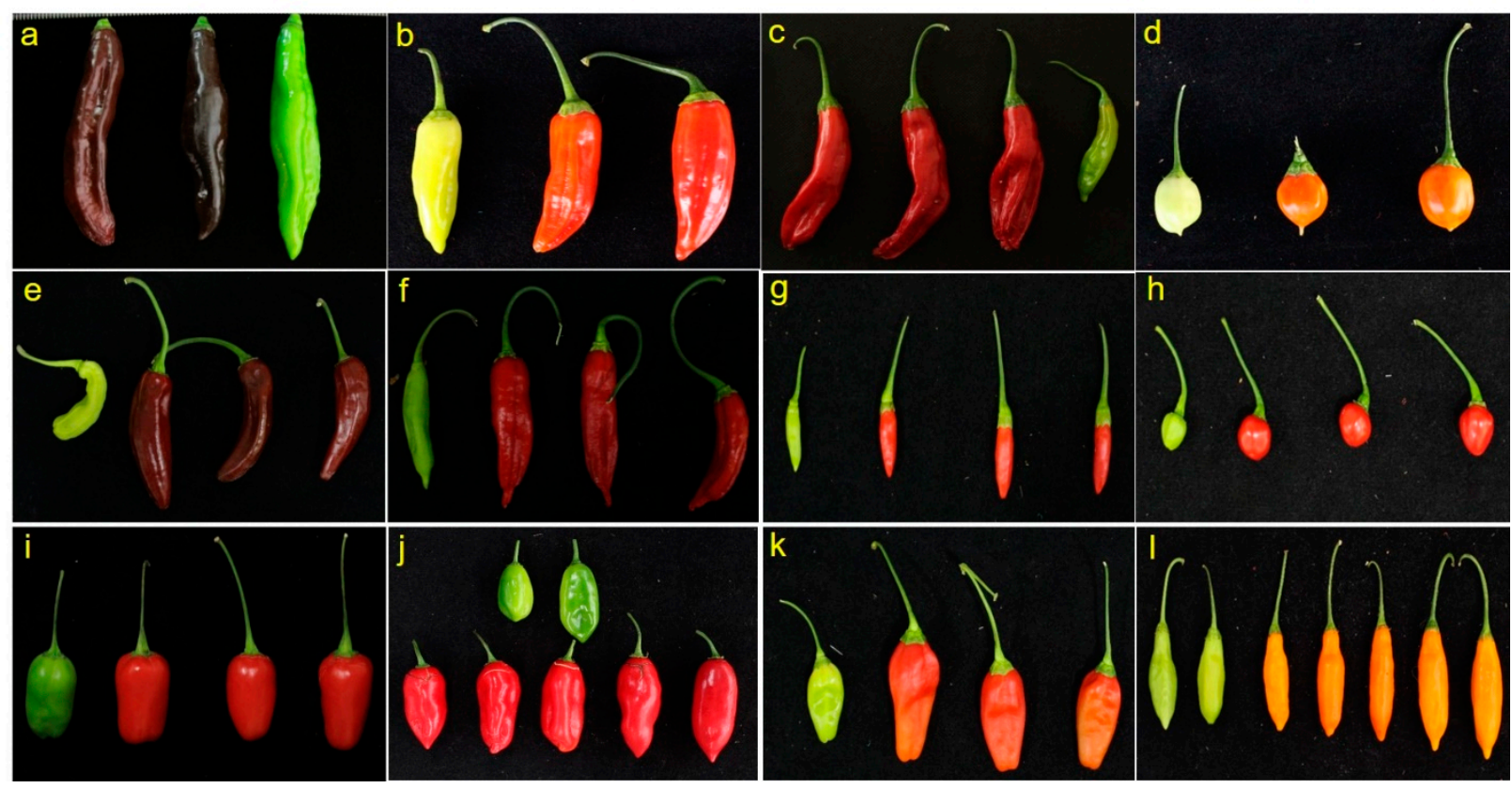

Figure 5. Fruit characteristics of anthracnose resistant pepper genetic resources selected for the inoculation study. (a) C. chinense; (b) C. baccatum var. pendulum; (c) C. baccatum var. baccatum; (d) C. baccatum var. baccatum; (e) C. chinense; (f) C. baccatum; (g) C. baccatum; (h) C. chinense; (i) C. frutescens; (j) C. chinense; (k) C. chinense; (1) C. baccatum.

\section{Discussion}

In the recent years, pepper anthracnose disease is becoming a major threat to Korean pepper production [34]. Evaluation of germplasm resources to find different resistance traits is an effective control method for Anthracnose (Colletotrichum spp.) disease resistance [14], which has high level of genetic diversity with different species and strains in the Korean regions [34]. Similarly, selection of plants carrying resistance genes are prerequisite for breeding studies. In pepper, molecular markers linked with anthracnose resistance genes have been identified and used in breeding programs [19]. Mainly two pepper cultivars sources are known to play a role in Anthracnose (Colletotrichum spp.) disease resistance [30]. The Korean genebank preserves about 6700 peppers collected from countries around the world. This study was conducted to determine the degree of resistance through non-wound and wound inoculation of $C$. acutatum on pepper fruit, and the selected resources were validated with molecular marker.

Based on the inoculation experiment, 261 resistant pepper genetic resources were selected successfully. In non-wound inoculation, C. baccatum and C. chinense, C. chacoense and C. frutescens were showed highly resistant to disease infection as reported previously $[13,21]$. The results of wound inoculation showed that the resistance resources were significantly distributed in the $C$. baccatum species when compared with other resources (Table 3). The C. baccatum species is known to exhibit stable resistance to various Colletotrichum spp. including C. capsici, C. gloeosporioides, C. acutatum species [28,35].

However, in wound inoculation, all the 215 tested accessions were developed anthracnose symptoms. Hence based on the inoculation experiments, wound inoculation method showed efficient for resistance evaluation, in which 12 resources with disease incidence rate of $0-25 \%$ were selected. The results showed there were some accessions with high incidence rates in wound inoculation, where they appeared strong resistance to non-wound inoculation. This is because the pepper anthracnose unable invades cell wall cuticle, resistance by initial defense such as cuticle layer and cell wall of plants [24,36]. It involves dynamic changes in the epidermis of the plant during pathogen infection, the crosstalk of various hormonal signaling pathways and cuticles for plant cell wall and 
plant disease resistance, and the major biochemical, molecular and cellular mechanisms responsible for the role of the cuticle during plant-pathogen interactions [37].

Plants recognize the attachment of pathogens and respond very quickly by inducing the innate immunity with microbe/pathogen associated molecular pattern [37]. DAMP, a product of pathogen-infected plant degradation, such as cutin monomers and cell wall oligosaccharides, also serves as a signal to activate plant defense against pathogens [38,39]. For instance, tomato fruit cuticle was changed in response to infection with the fungal pathogen C. gloeosporioides, and fruit cuticle biosynthesis was upregulated during appressorium formation even before penetration [40]. Similarly, during infection of citrus by C. acutatum, epidermal cells responded to pathogens by increasing lipid synthesis and deposition of cuticles and cell wall-related compounds, which eventually altered the cuticle structure [41]. The C. gloeosporioides induced the methyl jasmonate esterase was reported [42]. Jasmonates (JAs) has been demonstrated to be involved in plant resistance to pathogens by activating pathogenic related (PR) proteins such as PR-1, PR-3, and PR-8 [43]. Some PR genes were activated, including genes encoding pathogenesis-related protein 1 and a second pathogenicity-related protein [42].

Based on these findings, pepper resources that appear to be resistant in non-wound inoculation but to be susceptible in wound inoculation could have developed cuticles or defense signaling by JAs. However, wound inoculation method skipped up the step of the cuticle's defense mechanism, it would not be able to show resistance if there were no C. acutatum resistance genes inside the pepper genetic resources. The 12 resources that appeared as resistant resources in wound and non-wound inoculation are likely to have two defense mechanisms. First, the cuticles are used to defend against it, and the second is the resistance genes. Anthracnose resistance is controlled by a major resistance locus [15] and resistance to C. capsici in 'PBC932' was found to be controlled by a single recessive gene [34]. Resistance to C. acutatum derived from C. chinense 'PBC932' was stated to be controlled by two complementary dominant genes in green fruit, but by two recessive genes in red fruit [44]. Zhao et al. (2020) narrowed down the interval of a QTL AnRGO5 conferring resistance with fine-mapping analyses [26]. Based on these findings, it can be seen that the major genes or QTL involved in Capsicum anthracnose are present according to a specific pathogen and Capsicum species.

As a result of testing with CA12g19240 marker and CaR12.2M1-CAPS marker from selected accessions (Table 4), the markers for C. baccatum and C. annuum were well matched, but $C$. chinense and $C$. frutescens were susceptible although their phenotype to $C$. acutatum were resistant. As CA12g19240 marker and CaR12.2M1-CAPS marker were developed between $C$. baccatum and $C$. annuum, two makers could not distinguish resistance to C. acutatum in C. chinense and C. frutescens. Recently, a marker using PBC932 was developed [26]. However, it has not yet been applied to C. chinense genetic resource, it is expected that $C$. chinense can be used to determine resistance using a marker derived from PBC932. The CAPS and HRM markers have been reported to detect the intra- and interspecies variation and genotypic discrimination of different species [45]. Similarly, in this study CAPS and HRM markers have successfully identified the diversity between the Capsicum species.

The Capsicum species has been studied using morphological as well as with molecular markers [46]. The genetic similarity information can complement phenotypic information in the development of breeding populations [47]. Thus, morphological characterization is an important step in the classification of germplasm. Previously, Luitel et al. reported wide variation in the pepper fruit characters of a core collection [48]. Similarly, in this study the fruit characteristic analysis revealed that the selected pepper fruits vary in size, shape, color and even in their sugar content as the pepper germplasm collected from different countries. Since each country has different pepper preferences, selecting various anthracnose resistant genetic resources will help international pepper breeding. 


\section{Conclusions}

As being attempted worldwide to breed Capsicum for anthracnose resistant, it is important to evaluate various pepper germplasm and select excellent pepper genetic resources. In this study, a total of 261 accessions were selected which showed as resistance for nonwound inoculation. By selecting and testing them with wound inoculation experiment, 12 accessions were showed less than $25 \%$ of the disease incidence, indicating resistance. However, the CAPS and HRM markers analysis showed diversity of alleles, and hybrids in the tested accessions. Therefore, the findings of this study might provide useful information for understanding the genetic variability of tested accessions. Further, the validation of the CAPS and HRM markers which linked to anthracnose resistance revealed steady association of the marker in anthracnose-resistant accessions. These pepper genetic resources are expected to be used as materials for anthracnose-resistant breeding and genetic studies.

Author Contributions: Conceptualization, N.-Y.R. and B.-C.K.; methodology, O.-S.H. and B.G.; investigation, Y.-J.L. and R.S.; resources, G.-T.C.; data curation, N.-Y.R.; writing-original draft preparation, N.-Y.R.; writing-review and editing, R.S.; supervision, B.-C.K.; project administration, N.-Y.R. All authors have read and agreed to the published version of the manuscript.

Funding: This research received no external funding.

Institutional Review Board Statement: Not applicable.

Informed Consent Statement: Not applicable.

Acknowledgments: Financial support for the study was obtained from Research Program of Agricultural Science and Technology Development (Project No. PJ013251022020), National Institute of Agricultural Sciences, RDA, Republic of Korea.

Conflicts of Interest: The authors declare no conflict of interest.

\section{Appendix A}

Abbreviations of country names.

\begin{tabular}{cc}
\hline & Appendix A. Abbreviations of Country Names. \\
\hline Abbreviation & Nation \\
\hline 9 & Europe \\
27 & South America \\
AFG & Islamic State of Afghanistan \\
ARG & Argentine Republic \\
ARM & Republic of Armenia \\
AUS & Australia \\
AUT & Republic of Austria \\
AZE & Azerbaijani Republic \\
BEL & Kindgom of Belgium \\
BFA & Burkina Faso \\
BGD & People's Republic of Bangladesh \\
BGR & Republic of B $\mu$ L garia \\
BHS & Commonwealth of the Bahamas \\
BLR & Republic of Belarus \\
BLZ & Belize \\
BOL & Republic of Bolivia \\
BRA & Federative Republic of Brazil \\
BTN & Kingdom of Bhutan \\
BWA & Republic of Botswana \\
CAN & Canada \\
\hline
\end{tabular}


Appendix A. Abbreviations of Country Names.

\begin{tabular}{|c|c|}
\hline Abbreviation & Nation \\
\hline $\mathrm{CHE}$ & Swiss Confederation \\
\hline $\mathrm{CHL}$ & Republic of Chile \\
\hline $\mathrm{CHN}$ & People's Republic of China \\
\hline COL & Republic of Colombia \\
\hline CRI & Republic of Costa Rica \\
\hline CSK & Czechoslovakia \\
\hline CUB & Republic of Cuba \\
\hline CZE & Czech Republic \\
\hline DEU & Federal Republic of Germany \\
\hline DNK & Kingdom of Denmark \\
\hline DZA & People's Democratic Republic of Algeria \\
\hline ECU & Republic of Ecuador \\
\hline EGY & Arab Republic of Egypt \\
\hline ESP & Kingdom of Spain \\
\hline ETH & Ethiopia \\
\hline FJI & Republic of Fiji \\
\hline FRA & French Republic \\
\hline GAB & Gabonese Republic \\
\hline GBR & United Kingdom of Great Britain and Northern Ireland \\
\hline GEO & Republic of Georgia \\
\hline GIN & The Republic of Guinea \\
\hline GRC & The Hellenic Republic \\
\hline GRD & Grenada \\
\hline GTM & Republic of Guatemala \\
\hline GUY & Cooperative Republic of Guyana \\
\hline HND & Republic of Honduras \\
\hline HUN & Republic of Hungary \\
\hline IDN & Republic of Indonesia \\
\hline IND & Republic of India \\
\hline IRN & Islamic Republic of Iran \\
\hline IRQ & The Republic of Iraq \\
\hline ISR & State of Israel \\
\hline ITA & The Italian Republic \\
\hline JAM & Jamaica \\
\hline $\mathrm{JPN}$ & Japan \\
\hline KAZ & Republic of Kazakhstan \\
\hline KEN & The Republic of Kenya \\
\hline KGZ & Kyrgyz Republic \\
\hline KHM & Cambodia \\
\hline KOR & Republic of Korea \\
\hline LAO & Lao People's Democratic Republic \\
\hline LBY & Socialist People's Libyan Arab Jamahiriya \\
\hline LKA & Democratic Socialist Republic of Sri Lanka \\
\hline MAR & Kingdom of Morocco \\
\hline MDA & Republic of Moldova \\
\hline MDV & Republic of Maldives \\
\hline MEX & United Mexican States \\
\hline MMR & Union of Myanmar \\
\hline MNG & Mongolia \\
\hline MWI & Republic of Malawi \\
\hline MYS & Malaysia \\
\hline NGA & Federal Republic of Nigeria \\
\hline NIC & Republic of Nicaragua \\
\hline NLD & Kingdom of the Netherlands \\
\hline
\end{tabular}




\begin{tabular}{|c|c|}
\hline \multicolumn{2}{|c|}{ Appendix A. Abbreviations of Country Names. } \\
\hline Abbreviation & Nation \\
\hline NPL & Kingdom of Nepal \\
\hline PAK & Islamic Republic of Pakistan \\
\hline PAN & Republic of Panama \\
\hline PER & Republic of Peru \\
\hline PHL & Republic of the Philippines \\
\hline PNG & Papua New Guinea \\
\hline PRI & Puerto Rico \\
\hline PRK & Democratic People's Republic of Korea \\
\hline PRT & Portuguese Republic \\
\hline PRY & Republic of Paraguay \\
\hline $\mathrm{ROM}$ & Romania \\
\hline RUS & Russian Federation \\
\hline SDN & Republic of the Sudan \\
\hline SEN & Republic of Senegal \\
\hline SLV & Republic of El Salvador \\
\hline SRB & Republic of Serbia \\
\hline SUN & Union of Soviet Socialist Republics \\
\hline SUR & Republic of Suriname \\
\hline SVK & Slovak Republic \\
\hline SYR & Syrian Arab Republic \\
\hline THA & Kingdom of Thailand \\
\hline TJK & Republic of Tajikistan \\
\hline TKM & Turkmenistan \\
\hline TUN & Republic of Tunisia \\
\hline TUR & Republic of Turkey \\
\hline TWN & Taiwan Province of China \\
\hline TZA & United Republic of Tanzania \\
\hline UGA & Republic of Uganda \\
\hline UKR & Ukraine \\
\hline UNK & Unknown \\
\hline URY & Eastern Republic of Uruguay \\
\hline USA & United States of America \\
\hline UZB & Republic of Uzbekistan \\
\hline VEN & Republic of Venezuela \\
\hline VIR & Virgin Islands of the United States \\
\hline VNM & Socialist Republic of Viet Nam \\
\hline YEM & Republic of Yemen \\
\hline YUG & Federal Republic of Yugoslavia \\
\hline ZAR & Republic of Zaire \\
\hline $\mathrm{ZMB}$ & Republic of Zambia \\
\hline
\end{tabular}

\section{References}

1. Eshbaugh, W.H. The genus Capsicum (Solanaceae) in Africa. Bothalia 1983, 14, 4. [CrossRef]

2. Krishna De, A. Capsicum: The Genus Capsicum. Medicinal and Aromatic Plants-Industrial Profile; Taylor \& Francis: London, UK; New York, NY, USA, 2003; Volume 33, p. 275.

3. Davenport, L.J. Genera Solanacearum: The Genera of Solanaceae Illustrated, Arranged According to a New System by Armando T. Hunziker. Syst. Bot. 2004, 29, 221-222. [CrossRef]

4. Gonzalez-Perez, S.; Garces-Claver, A.; Mallor, C.; Saenz de Miera, L.E.; Fayos, O.; Pomar, F.; Merino, F.; Silvar, C. New insights into Capsicum spp. relatedness and the diversification process of Capsicum annuum in Spain. PLoS ONE 2014, 9, e116276. [CrossRef]

5. Pozzobon, M.T.; Schifino-Wittmann, M.T.; De Bem Bianchetti, L. Chromosome numbers in wild and semidomesticated Brazilian Capsicum L. (Solanaceae) species: Do $x=12$ and $x=13$ represent two evolutionary lines? Bot. J. Linn. Soc. 2006, 151, 259-269. [CrossRef]

6. Moscone, E.A.; Scaldaferro, M.A.; Grabiele, M.; Cecchini, N.M.; Sánchez García, Y.; Jarret, R.; Daviña, J.R.; Ducasse, D.A.; Barboza, G.E.; Ehrendorfer, F. The Evolution of Chili Peppers (Capsicum-Solanaceae): A Cytogenetic Perspective. Act. Hortic. 2007, 137-169. [CrossRef] 
7. Hernandez-Verdugo, S.; Guevara-Gonzalez, R.G.; Rivera-Bustamante, R.F.; Oyama, K. Screening wild plants of Capsicum annuum for resistance to pepper huasteco virus (PHV): Presence of viral DNA and differentiation among populations. Euphytica 2001, 122, 31-36. [CrossRef]

8. Hammer, K.; Arrowsmith, N.; Gladis, T. Agrobiodiversity with emphasis on plant genetic resources. Naturwissenschaften 2003, 90, 241-250. [CrossRef] [PubMed]

9. Than, P.P.; Prihastuti, H.; Phoulivong, S.; Taylor, P.W.J.; Hyde, K.D. Chilli anthracnose disease caused by Colletotrichum species. J. Zhejiang Univ. Sci. B 2008, 9, 764. [CrossRef]

10. Kang, B.K.; Kim, J.H.; Lee, K.H.; Lim, S.C.; Ji, J.J.; Lee, J.W.; Kim, H.T. Effects of Temperature and Moisture on the Survival of Colletotrichum acutatum, the Causal Agent of Pepper Anthracnose in Soil and Pepper Fruit Debris. Plant Pathol. J. 2009, 25, 128-135. [CrossRef]

11. Manandhar, J.B.; Hartman, G.L. Anthracnose development on pepper fruits inoculated with Colletotrichum gloeosporioides. Plant Dis. 1995, 79, 380-383. [CrossRef]

12. Srikhong, P.; Lertmongkonthum, K.; Sowanpreecha, R.; Rerngsamran, P. Bacillus sp. strain M10 as a potential biocontrol agent protecting chili pepper and tomato fruits from anthracnose disease caused by Colletotrichum capsici. BioControl 2018, 63, 833-842. [CrossRef]

13. Park, S.-K.; Kim, S.H.; Park, H.; Yoon, J. Capsicum Germplasm Resistant to Pepper Anthracnose Differentially Interact with Colletotrichum Isolates. Hortic. Environ. Biotechnol. 2009, 50, 17-23.

14. Lee, J.; Hong, J.-H.; Do, J.W.; Yoon, J.B. Identification of QTLs for resistance to anthracnose to two Colletotrichum species in pepper. J. Crop Sci. Biotechnol. 2010, 13, 227-233. [CrossRef]

15. Lee, J.; Do, J.W.; Yoon, J.B. Development of STS markers linked to the major QTLs for resistance to the pepper anthracnose caused by Colletotrichum acutatum and C. capsici. Hortic. Environ. Biotechnol. 2011, 52, 596-601. [CrossRef]

16. Yoon, J.; Park, H. Trispecies Bridge Crosses, (Capsicum annuum $\times$ C. chinense) $\times$ C. baccatum, as an Alternative for Introgression of AnthracnoseResistance from C. baccatum into C. annuum. Hortic. Environ. Biotechnol. 2005, 46, 5-9.

17. AVRDC (Ed.) Host resistance to pepper anthracnose. In AVRDC Report; AVRDC-The World Vegetable Centre: Shanhua, Taiwan, 2003; pp. 29-30.

18. Pakdeevaraporn, P.; Wasee, S.; Taylor, P.W.J.; Mongkolporn, O. Inheritance of resistance to anthracnose caused by Colletotrichum capsici in Capsicum. Plant Breed. 2005, 124, 206-208. [CrossRef]

19. Ridzuan, R.; Rafii, M.Y.; Ismail, S.I.; Mohammad Yusoff, M.; Miah, G.; Usman, M. Breeding for Anthracnose Disease Resistance in Chili: Progress and Prospects. Int. J. Mol. Sci. 2018, 19, 3122. [CrossRef] [PubMed]

20. Yoon, J.B.; Do, J.W.; Yang, D.C.; Park, H.G. Interspecific Cross Compatibility among Five Domesticated Species of Capsicum Genus. Hortic. Environ. Biotechnol. 2004, 45, 324-329.

21. Kim, S.-G.; Ro, N.-Y.; Hur, O.-S.; Ko, H.-C.; Gwag, J.-G.; Huh, Y.-C. Evaluation of Resistance to Colletotrichum acutatum in Pepper Genetic Resources. Res. Plant Dis. 2012, 18, 93-100. [CrossRef]

22. Su, K.; Ki-taek, K.; DongHwi, K.; EunYoung, Y.; MyeongCheoul, C.; Jamal, A.; Young, C.; DoHam, P.; DaeGeun, O.; JuKwang, H. Identification of quantitative trait loci associated with anthracnose resistance in chili pepper (Capsicum spp.). Korean J. Hortic. Sci. Technol. 2010, 28, 1014-1024.

23. Kim, K.H.; Yoon, J.B.; Park, H.G.; Park, E.W.; Kim, Y.H. Structural Modifications and Programmed Cell Death of Chili Pepper Fruit Related to Resistance Responses to Colletotrichum gloeosporioides Infection. Phytopathology 2004, 94, 1295-1304. [CrossRef] [PubMed]

24. Oh, B.J.; Kim, K.D.; Kim, Y.S. Effect of Cuticular Wax Layers of Green and Red Pepper Fruits on Infection by Colletotrichum gloeosporioides. J. Phytopathol. 1999, 147, 547-552. [CrossRef]

25. Suwor, P.; Thummabenjapone, P.; Sanitchon, J.; Kumar, S.; Techawongstien, S. Phenotypic and genotypic responses of chili (Capsicum annuum L.) progressive lines with different resistant genes against anthracnose pathogen (Colletotrichum spp.). Eur. J. Plant Pathol. 2015, 143, 725-736. [CrossRef]

26. Zhao, Y.; Liu, Y.; Zhang, Z.; Cao, Y.; Yu, H.; Ma, W.; Zhang, B.; Wang, R.; Gao, J.; Wang, L. Fine mapping of the major anthracnose resistance QTL AnRGO5 in Capsicum chinense 'PBC932'. BMC Plant Biol. 2020, 20, 189. [CrossRef] [PubMed]

27. Mahasuk, P.; Khumpeng, N.; Wasee, S.; Taylor, P.W.J.; Mongkolporn, O. Inheritance of resistance to anthracnose (Colletotrichum capsici) at seedling and fruiting stages in chili pepper (Capsicum spp.). Plant Breed. 2009, 128, 701-706. [CrossRef]

28. Mahasuk, P.; Taylor, P.W.J.; Mongkolporn, O. Identification of Two New Genes Conferring Resistance to Colletotrichum acutatum in Capsicum baccatum. Phytopathology® 2009, 99, 1100-1104. [CrossRef] [PubMed]

29. Mahasuk, P.; Struss, D.; Mongkolporn, O. QTLs for resistance to anthracnose identified in two Capsicum sources. Mol. Breed. 2016, 36, 10. [CrossRef]

30. Kim, S.H.; Yoon, J.B.; Park, H.G. Inheritance of anthracnose resistance in a new genetic resource, Capsicum baccatum PI594137. J. Crop Sci. Biotechnol. 2008, 11, 13-16.

31. Kim, H.; Yoon, J.B.; Lee, J. Development of Fluidigm SNP Type Genotyping Assays for Marker-assisted Breeding of Chili Pepper (Capsicum annuum L.). Hortic. Sci. Technol. 2017, 35, 465-479. [CrossRef]

32. Lee, Y.R.; Kim, J.; Lee, S.Y.; Lee, J. Diallelic SNP marker development and genetic linkage map construction in octoploid strawberry (Fragaria $\times$ ananassa) through next-generation resequencing and high-resolution melting analysis. Hortic. Environ. Biotechnol. 2020, 61, 371-383. [CrossRef] 
33. RDA. Pepper (Capsicum spp.). Rural Development Administration, Korea, 2012, pp. 1-53. Available online: http:/ / www.rda.go. $\mathrm{kr} /$ foreign/ten/index.jsp (accessed on 18 August 2021).

34. Kim, J.-T.; Kim, J.; Park, S.; Choi, W. Characterization of Colletotrichum Isolates Causing Anthracnose of Pepper in Korea. Plant Pathol. J. 2008, 24, 17-23. [CrossRef]

35. Montri, P.; Taylor, P.W.J.; Mongkolporn, O. Pathotypes of Colletotrichum capsici, the Causal Agent of Chili Anthracnose, in Thailand. Plant Dis. 2009, 93, 17-20. [CrossRef] [PubMed]

36. Kim, S.-G. Structural Changes in the Development of Phytophthora Blight and Anthracnose on Chili Pepper (Capsicum annuum L.). Ph.D. Thesis, Seoul National University, Seoul, Korea, 2009.

37. Ziv, C.; Zhao, Z.; Gao, Y.G.; Xia, Y. Multifunctional Roles of Plant Cuticle During Plant-Pathogen Interactions. Front. Plant Sci. 2018, 9, 1088. [CrossRef]

38. Underwood, W. The Plant Cell Wall: A Dynamic Barrier Against Pathogen Invasion. Front. Plant Sci. $2012,3,85$. [CrossRef] [PubMed]

39. Malinovsky, F.G.; Fangel, J.U.; Willats, W.G.T. The role of the cell wall in plant immunity. Front. Plant Sci. 2014, 5, 178. [CrossRef] [PubMed]

40. Alkan, N.; Friedlander, G.; Ment, D.; Prusky, D.; Fluhr, R. Simultaneous transcriptome analysis of Colletotrichum gloeosporioides and tomato fruit pathosystem reveals novel fungal pathogenicity and fruit defense strategies. New Phytol. 2015, 205, 801-815. [CrossRef]

41. Marques, J.P.R.; Amorim, L.; Spósito, M.B.; Appezzato-da-Glória, B. Ultrastructural changes in the epidermis of petals of the sweet orange infected by Colletotrichum acutatum. Protoplasma 2016, 253, 1233-1242. [CrossRef] [PubMed]

42. Ziv, C.; Kumar, D.; Sela, N.; Itkin, M.; Malitsky, S.; Schaffer, A.A.; Prusky, D.B. Sugar-regulated susceptibility of tomato fruit to Colletotrichum and Penicillium requires differential mechanisms of pathogenicity and fruit responses. Environ. Microbiol. 2020, 22, 2870-2891. [CrossRef] [PubMed]

43. Reymond, P.; Farmer, E.E. Jasmonate and salicylate as global signals for defense gene expression. Curr. Opin. Plant Biol. 1998, 1, 404-411. [CrossRef]

44. Lin, S.W.; Gniffke, P.A.; Wang, T.C. Inheritance of Resistance to Pepper Anthracnose Caused by Colletotrichum acutatum. Acta. Hortic. 2007, 329-334. [CrossRef]

45. Jo, I.-H.; Sung, J.; Hong, C.-E.; Raveendar, S.; Bang, K.-H.; Chung, J.-W. Development of cleaved amplified polymorphic sequence (CAPS) and high-resolution melting (HRM) markers from the chloroplast genome of Glycyrrhiza species. 3 Biotech 2018, 8, 220. [CrossRef] [PubMed]

46. Geleta, L.F.; Labuschagne, M.T.; Viljoen, C.D. Genetic Variability in Pepper (Capsicum annuum L.) Estimated by Morphological Data and Amplified Fragment Length Polymorphism Markers. Biodivers. Conserv. 2005, 14, 2361-2375. [CrossRef]

47. Greene, S.L.; Gritsenko, M.; Vandemark, G. Relating Morphologic and RAPD Marker Varlation to Collection Site Environment in wild Populations of Red Clover (Trifolium Pratense L.). Genet. Resour. Crop Evol. 2004, 51, 643-653. [CrossRef]

48. Luitel, B.P.; Ro, N.-Y.; Ko, H.-C.; Sung, J.-S.; Rhee, J.-H.; Hur, O.-S. Phenotypic Variation in a Germplasm Collection of Pepper (Capsicum chinense Jacq.) from Korea. J. Crop Sci. Biotechnol. 2018, 21, 499-506. [CrossRef] 